\title{
Corporate Criminal Liability Under the Reactive Corporate Fault to Achieve Good Corporate Governance in Indonesia
}

\author{
Budi Suhariyanto* \\ ${ }^{1}$ Ph.D Student of Postgraduate Program Universitas Indonesia, 16424, Jakarta, Indonesia
}

\begin{abstract}
This article discusses the existence, mechanisms and the ideal model of corporate criminal liability based reactive corporate fault for achieving good corporate governance in Indonesia. Implementation of reactive corporate fault doctrine is essential as a basis the prosecution of criminal responsibility in the case that the corporate lets the occurence of criminal act of its managers or does not do prevention through corrective measures in order to avoid repetition. This doctrine needs to be accommodated in the draft of Indonesian Criminal Code (KUHP) in order to put pressure on the corporation that intends creating good internal control (so as not to be blamed) based on good corporate governance.
\end{abstract}

\section{Introduction and literature review}

Strategic role of corporations in improving social welfare and economic development of the country. However, in reality there are also corporations that are used to commit the crime and causing losses to the state. Legislation in Indonesia have set up the corporation as a subject of a criminal act that can be blamed and sued against criminal liability. Supreme Court through the Supreme Court Regulation No. 13 of 2016 on Procedures for Handling Criminal Acts by the Corporation (Perma) has provided guidance to judges in assessing corporate fault namely based on (Article 4 section (2)):

a. Corporation can get benefit or the advantages of a criminal act or criminal act was committed for the benefit of the corporation;

b. Corporation allows the occurence of criminal acts: or

c. Corporation does not undertake the necessary measures for the prevention, preventing a greater impact and ensure compliance with applicable laws and regulations in order to avoid the occurrence of a crime.

In connection with article 4 , section (2) point c above, the doctrine of corporate criminal liability is known as reactive corporate fault (RCF). According to this doctrine, the corporation could only avoid liability if it can prove that the corporation has made adequate procedure to prevent all crimes committed by the personnel or organs of the corporate. Ratio legis of accomodation of this doctrine is that the corporation constantly implement and embody the principles of Good Corporate Governance (GCG) in aspects of behavior,

* Coresponding author: penelitihukumma@gmail.com 
policies, rules and training to personnel both inside and outside the organ that has a working relationship and other relationships with the corporation. It is interesting to do assessments related to corporate criminal liability by RCF in order to realize the GCG in Indonesia.

\subsection{Overview of the doctrine of corporate criminal liability}

At present it has accommodated the criminal responsibility other than human (persoon), namely corporation (recht persoon). There are several theories widely adopted as theories used to assess the criminal liability of corporations, namely: First, the doctrine of strict criminal responsibility according to the law (strict liability), so the responsibility of corporations solely based on sound legislation with regardless of who do error. Second, the doctrine of vicarious liability, emphasizing greater on accountability by the management of the corporation as an "agent" of actions of the corporation. Third, the theory of identification or the doctrine of direct corporate criminal liability can perform a number of offenses directly through the people who are closely associated with the company and are deemed as the company itself. Fourth, the aggregation theory which states that criminal liability can be imposed on a legal entity if it was committed by a number of people who meet the elements of the offense one another interrelated and did not stand on their own. Fifth, the doctrine of corporate culture model is the doctrine that focuses on explicit and implicit policy of legal entities affects the workings of the legal entity. Legal entity may be criminally accountable when the actions of a person have a rational basis that the legal entity authorizes or permits the action to be committed [1]. Sixth, the theory of RCF is that a mistake of corporation is not an error at the time the crime occurred but the errors because the corporation failed to take proper action upon mistakes made by its employees [2].

\subsection{Theoretical study on RCF}

The theory of the corporation fault known with the theory of RCF was put forward by the Fisse and John Braithwaiten. According to this theory, the disconnection of the restrictive individualistic character and derivative character of the theories in which the model of error is made to be "non-prosecution responsive manager" arising from the intent of the company concerned. Under the reactive error, companies or corporations make himself responsible for observing and reporting on internal discipline, after an offense (including the criminal act) occurs and also resolve these responsibilities. Reactive corporate fault can be broadly defined as the failure of the company or corporation that does not deserve to have and implement preventive or corrective action against a violation by personal acting for and on behalf of the corporation. If the corporation has taken the proper precautions, there is no imposition of liability form, addressed to the corporation concerned [3].

\subsection{Theoretical study of GCG}

Over the last ten years, the term corporate governance is becoming popular. Not only popular, the term is also placed in the top rank. GCG is one of success keys of company to grow and to be profitable in the long term, while to win the global business competition. GCG is a system (input, process, output) and a set of rules that govern the relationship between the 
various parties (stakeholders), especially in the narrow sense of the relationship between shareholders, board of directors, and the board of Directors for the achievement of corporate objectives. GCG is to manage these relationships and prevent significant errors in corporate strategy and to ensure that the errors that occur can be corrected by the State. There are five principles of GCG that can be used as guidelines for businesses, namely Transparency, Accountability, Responsibility, Independency and Fairness [4].

\section{Objective of the study}

This study raised several issues relevant to the topic of discussion, namely: (1). How does the existence of criminal liability corporation based RCF in Indonesia legislation? (2). How is authentication mechanism of corporate error element based on the RCF doctrine? (3). How does the ideal model of corporate criminal liability arrangements based on the doctrine of the RCF to realize GCG in Indonesia?

\section{Methodology}

To answer and discuss the problems that become the object of study above, the author uses the method of normative legal research using statutory approach and conceptual approaches. Law approach is used to determine the hierarchy and principles in legislation as well as to determine the ratio legis and the basic of ontological [5] of corporate criminal liability by RCF. While the conceptual approach is used to assess the existence of criminal liability corporation based RCF associated with the views and doctrines of legal experts [6].

\section{Discussion}

\subsection{Existence of corporate criminal liability by RCF in Indonesia legislation}

Indonesian Criminal Code has not yet recognized the corporation as a subject of criminal law. General provisions of the Indonesian Criminal Code until now still do not put the corporation as a subject of criminal law [7]. In further developments, the legislation that is outside the Indonesian Criminal Code begins to recognize corporations as legal subjects that are enforceable to criminal liability [8]. The doctrine of corporate criminal liability accommodated by legislation outside the Indonesian Criminal Code varies, some being to apply the doctrine of identification and aggregation, while others apply the doctrine of strict liability, vicarious liability and RCF.

As a guideline in completing the application of the laws governing corporate criminal prosecution, Perma accommodates the doctrine of corporate criminal liability in full namely based on the theory of identification, aggregation, strict liability, vicarious liability, corporate culture and the model of RCF. The existence of the doctrine of RCF is governed by Article 4 section (2) c Perma stating that the corporation can be blamed if it does not perform the steps necessary for the prevention, preventing a greater impact and ensure compliance with applicable laws and regulations in order to avoid the occurence of criminal act.

Observing the position of Perma is under the law, then the substantive regulation must not conflict with the law, including in the case of applying the doctrine of RCF. Although Perma regulates corporate criminal liability by the doctrine of RCF, but because not all the 
legislation governing the corporation to accommodate the RCF doctrine, so only against certain types of criminal acts that can be prosecuted responsibility of corporations using the RCF doctrine. For example in environmental crime as defined by the explanation of Article 118 of Law No. 32 of 2009 on the Protection and Management of the Environment stating that "intended to receive action in this Article shall include approved, allow, or not enough to supervise the physical perpetrator's actions, and / or have policies that allow for such offenses ".

\subsection{The proof mechanism of corporate error element based on the doctrine of RCF}

Normatively, Perma does not provide an explanation of the error element of proof mechanism by RCF. In practice, this time in the law enforcement refute the corporation is looking at the Articles of Association and Bylaws (AD / ART) and Standard Operating Procedure (SOP) is connected with the board that represent corporate actions in committing a crime. this is in accordance with the Regulation of the Attorney General No. PER-28 / A / JA / 10/2014 on Guidelines for Handling Criminal Cases By Subject Law of Corporations (short busines) that investigators must conduct seizures of AD / ART and deed another (SOP) in terms of establishing the corporation as a suspect.

By study of Investigator to corporate internal regulation will be effective for assessing the correct company policies and to assess an act done contrary to the rules of the corporation or not [9]. If the company or a corporation is considered to have done the right thing for resolving the problem, then the criminal liability will not be imposed on the corporation concerned. When rated on the contrary, where the corporation considered not taking action or insufficient measures in order to tackle the crime, then the corporation in question could be liable to criminal (criminal responsibility because it has been negligent not fulfill the orders of the court or for an opportunity to do a criminal act) [10].

In judicial practice, the application of the RCF can be categorized as a justification or reasons that justify criminal punishment for corporations (Perma states "in criminalize corporation" and "to assess the corporate fault"). However, it can also be used as an excuse (reason that eliminate errors) for the corporation so that the corporation cannot be held accountable in criminal or at least as an excuse that can be considered by the judges as a mitigating excuse in case the judge ruled on the criminal for the corporation [11]. In this context, the disparity in sentencing verdict is likely to occur.

\subsection{The ideal model of corporate criminal liability arrangements based on the doctrine of the RCF to realize GCG in Indonesia}

To anticipate the verdict sentencing disparity would create legal uncertainty it would require a mechanism for setting corporate refutation by RCF in legislation. The draft of Indonesian Criminal Code (draft 2015) has not been set by the doctrine of corporate criminal liability RCF. Observing the importance of setting corporate criminal liability by the doctrine of RCF to realize GCG in Indonesia, then it needs to be regulated in the draft Criminal Code. 
If RCF included in the draft of Indonesian Criminal Code, the regulations can be found to an act which constitutes a criminal act carried out by or on behalf of a corporation, the court should be given the authority to order the corporation to conduct its own investigation to ensure those responsible and take appropriate disciplinary action for the mistakes the person and take corrective measures to ensure that such mistakes will not be repeated [12]. As a form of accountability that can be held against the corporation for example [13]:

a. Asking the company or corporation to investigate who is responsible for the organization of the company or corporation:

b. Taking disciplinary action against those responsible:

c. Ordering the company or send a detailed report on what actions have been taken by the company to resolve the issue.

Forms of corporate criminal liability based RCF above occur if the corporation failed to take preventive measures or corrective action in response to a criminal act (actus reus) conducted by personnel of the corporation. The consideration is not the question of whether the corporation has a policy to obey the law or not, but whether corporate conduct internal disciplinary measures, structural reforms, and compensation in response to the actus reus done by employees [14]. If the corporate responsibility over the initial error can be classified as corporate responsibility for the actions of a person (so that corporate responsibility is an instance of personal accountability), the corporate responsibility for mistakes reactive rather a corporate responsibility on its own mistakes [15] which does not ensure itself to do prevention and control of criminal acts committed repeatedly by employees.

Through RCF accommodation in the Indonesian Criminal Code in the future (when designs are passed by the House of Representatives), then the corporation will always strive to improve the internal control system through the reform-related regulations and SOPs corporate structure. With the corporate internal control system, the crime of the board will be prevented. When the "already" the criminal act by the board then the spontaneous response to the corporation in providing disciplinary action against the concerned officials and prevent the repetition is of great importance to free corporations from RCF error. In this context, GCG will grow on any corporation in Indonesia so that the improvement of national and global economic systems.

\section{Conclusion}

Corporate Criminal Liability based RCF is set in the explanation of Article 118 of Law No. 32 of 2009 and Article 4 section (2) c Perma. With regard to no complete explanation of the law on the RCF proof mechanism then the law enforcement officers use base from General Attorney Regulation and the judges must interpret in accordance with his belief in making the RCF as a justification or an excuse to errors of corporation. Observing the importance of the implementation of the RCF in creating GCG then the presence needs to be included in national criminal law reform (draft of Indonesian Criminal Code). 


\section{References}

1. Eddy O.S. Hiariej, The Principles of Criminal Law (Cahaya Atma Pustaka, Yogyakarta, 2014)

2. A. H. Semendawai, Corporate Criminal Responsibility in RUU KUHP, (Elsam, Jakarta, 2005)

3. Brent Fisse \& John Braithwalte, Corporations, Crime, and Accountability, (Cambridge University Press, Cambridge, 1993).

4. Siswi Wulandari, Good Corporate Governance in the Perspective of Business Ethics, Journal Applied Business and Economic, Volume 1, Number 3, March 2015

5. Peter Mahmud Marzuki, Legal Research, (Kencana, Jakarta, 2014)

6. H.P. Panggabean, Application of Legal Theory in the Indonesia Justice System, (Alumni, Bandung, 2014)

7. Hasbullah F. Sjawie, Limited Company Directors and Corporate Criminal Responsibility, (Citra Aditya Bhakti, Bandung, 2013)

8. Budi Suhariyanto, The Role of Regulation of the Supreme Court Number 13 Year 2016 in Overcoming the Obstacles of Corporation Criminal Infringement, Jurnal Negara Hukum, Volume 9, Number 1, June 2018

9. Kristian, The System of Corporate Criminal Responsibility: Theoritical Review and Comparative of Law in the Various Countries, (Refika Aditama, Bandung, 2016)

10. Kristian, Corporate Criminal Law: Integral Formulation Policy of Corporate Criminal Responsibility, (Nuansa Aulia, Bandung, 2014)

11. Kristian, The System of Corporate Criminal Responsibility in the Corruption Case dalam Perkara Tindak Pidana Korupsi After Publication the Supreme Court Number 13 Year 2016, (Sinar Grafika, Jakarta, 2018)

12. Jimmy Tawalujan, Corporate Responsibility for Victims of Crime, Jurnal Lex Crimen Volume 1, Number 3, July-September 2012

13. Rise Karmilia, The Regulation of Corporate Criminal Responsibility on Criminal Provisions outside KUHP, Thesis, North Sumatera University, 2009

14. Brent Fisse dan John Braithwaite, The Allocation of Responsibility for Corporate Crime: Individualism, Collectivism and Accountability, Sydney Law Review, Volume 11, 1988

15. Andri G. Wibisana, Enviromental Crime by Corporation: Looking for Shapes of Corporate Responsibility and Corproate Leader/Manager for Enviromental Crime in Indonesia, Jurnal Hukum \& Pembangunan, Volume 46, Number 2, 2016 